\title{
Wyrok Trybunału Sprawiedliwości Unii Europejskiej z perspektywy kognitywnej teorii prototypu. Studium przypadku²
}

\section{Wprowadzenie}

Według wielu ujęć teoretycznych, wątpliwości interpretacyjne w stosowaniu prawa rodzą się z rozbieżności pomiędzy językiem przepisu a faktami ${ }^{3}$. Takie postawienie sprawy, które co do zasady uważam za trafne, czyni problem kategoryzacji interesującym przedmiotem badań dla prawnika. W niniejszym artykule zreferuję pokrótce teorię kategoryzacji zwaną teorią prototypu (prototype theory), aby następnie wykorzystać ją do analizy wyroku Trybunału Sprawiedliwości Unii Europejskiej (dalej: „TSUE”).

Przez stulecia w filozofii i nauce (w tym nauce prawa) dominowała tzw. klasyczna teoria kategoryzacji, której autorstwo przypisuje się zwykle Arystotelesowi ${ }^{4}$. Teoria klasyczna zakłada, że każda kategoria pojęciowa posiada swoją istotę, tj. zestaw cech, których łączne spełnienie powoduje zakwalifikowanie obiektu jako przedstawiciela danej kategorii. Przykładowo, dla Arystotelesa istotą kategorii CZŁOWIEK jest bycie zwierzęciem dwunożnym, a więc łączne spełnianie cech: 'zwierzę' oraz 'dwunożne'. Spełnianie innych cech np. 'wysoki', 'czarnoskóry', 'inteligentny', 'kobiecy' itd. nie ma wpływu na kategoryzację danego obiektu, ponieważ są to cechy przypadkowe, a nie istotne ${ }^{5}$. Poglądy Arystotelesa na kategoryzację odcisnęły piętno na wielu dziedzinach nauki. W lingwistyce ich ukoronowaniem jest tzw. analiza składnikowa, czyli procedura ustalania wartości semantycznej wyrazu poprzez rozkład jego znaczenia na elementarne, uniwersalne i abstrakcyjne składniki semantyczne. Słynnym przykładem jest wyraz kawaler,

Numer ORCID: 0000-0003-3266-3397. Adres e-mail: mateusz.zeifert@us.edu.pl

Artykuł powstał w ramach realizacji grantu badawczego Znaczenie tekstu prawnego $w$ świetle wybranych koncepcji językoznawstwa kognitywnego, finansowanego przez Narodowe Centrum Nauki (projekt badawczy nr 2018/31/D /HS5/03922).

3 "Most disputes over the meanings of statutes are about the fit between events in the world and the words in the statute". L.M. Solan, The Language of Statutes. Laws and Their Interpretation, Chicago-Londyn 2010, s. 50. Por. np. H.L.A. Hart, Pojęcie prawa, Warszawa 1998, s. 174 i n.; J. Wróblewski, Rozumienie prawa i jego wyktadnia, Wrocław-Warszawa-Kraków-Gdańsk-Lódź 1990, s. 76 i n.; A. Kaufmann, Od prawa natury i pozytywizmu prawniczego do hermeneutyki prawniczej, w: J. Zajadło, Kaufmann, Sopot 2018, s. 22-23.

4 Por. D. Geeraerts, Prospects and Problems of Prototype Theory, Language, „Linguistic” 1989/4, s. 6, przypis 13.

5 J. Taylor, Kategoryzacja w języku. Prototypy w teorii językoznawczej, Kraków 2001, s. 45-64. 
którego znaczenie można opisać za pomocą zestawu składników: 'ludzki', 'męski', 'dorosły', 'nigdy nieżonaty'.

Od połowy lat 70. XX w. klasyczna teoria kategoryzacji zaczęła być intensywnie weryfikowana i kwestionowana na gruncie empirycznym. Amerykańska badaczka, Eleanor Rosch przeprowadziła szereg eksperymentów psychologicznych dotyczących kategoryzowania świata przez ludzi. Eksperymenty dotyczyły rozmaitych kategorii pojęciowych, m.in. nazw barw, ptaków czy mebli ${ }^{7}$ Wyniki tych badań postawiły pod znakiem zapytania realność psychologiczną klasycznej teorii kategoryzacji. Okazało się bowiem, że w ocenie ankietowanych niektóre obiekty są „lepszymi” przedstawicielami danej kategorii niż inne (np. pewien odcień czerwieni jest bardziej „czerwony” niż inne, drozd jest „lepszym” ptakiem niż struś, a krzesło „lepszym” meblem niż lampa). Doprowadziło to do postawienia tezy, że kategorie pojęciowe mają złożoną strukturę wewnętrzną: „w centrum” znajduje się prototyp, tj. najbardziej reprezentatywny okaz, „na peryferiach” zaś okazy nietypowe odbiegające od prototypu. Mechanizm przypisania przynależności do kategorii polega na ocenie podobieństwa danego okazu do prototypu, a nie na ustaleniu spełniania przez ten okaz zestawu określonych cech. Kolejnym krokiem było zakwestionowanie granic pomiędzy kategoriami - skoro przynależność do kategorii może być stopniowalna, nie jest wykluczone, że ten sam okaz może zostać zaliczony do kilku różnych, „sąsiadujących” kategorii, co stoi oczywiście w sprzeczności z Arystotelesowską zasadą wyłączonego środka.

Publikacje E. Rosch spotkały się z szerokim odzewem, zwłaszcza w psychologii ${ }^{8}$, teorii sztucznej inteligencji ${ }^{9}$ i językoznawstwie. Dla naszych rozważań istotna jest recepcja teorii prototypu w językoznawstwie teoretycznym (lingwistyce). Językoznawstwo w latach 70. zdominowane było przez teorię transformacyjno-generatywną Noama Chomsky'ego, która w warstwie semantycznej (tzw. komponent semantyczny) wykorzystywała wspomnianą już metodę analizy składnikowej ${ }^{10}$. Podejście takie nie spełniło jednak pokładanych w nim nadziei i poszczególni autorzy - w tym dawni uczniowie N. Chomsky'ego - zaczęli odrzucać jego rygorystyczne założenia, szukając bardziej adekwatnych narzędzi opisu znaczenia językowego. Takim narzędziem okazała się teoria prototypu, która bardzo szybko została podchwycona przez lingwistów z kształtującego się w tamtym okresie nowego nurtu nazwanego językoznawstwem kognitywnym ${ }^{11}$.

\section{Teoria prototypu}

Po naświetleniu historycznego kontekstu powstania teorii prototypu, wypada przejść do próby jej zrekonstruowania. Z kilku względów nie jest to prosta sprawa. Po pierwsze,

\footnotetext{
Por. J. Taylor, Kategoryzacja ..., s. 55-64.

Por. m.in. E. Rosch, Natural Categories, „Cognitive Psychology” 1973/4, s. 328-350; E. Rosch, Cognitive Representations of Semantic Categories, „Journal of Experimental Psychology: General” 1975/104, s. 192-233; E. Rosch, Principles of Categorization, w: E. Rosch, B.B. Lloyd (red.), Cognition and Categorization, Hillsdale 1978, s. 251-270.

8 Por. np. J. Hampton, Concepts as prototypes, ,The Psychology of Learning and Motivation” 2006/46, s. 79-113.

9 Por. np. J. Lawry, Y. Tang, Uncertainty modelling for vague concepts: A prototype theory approach, „Artificial Intelligence" 2009/173, s. 1539-1558.

10 Por. J.J. Katz, J.A. Fodor, The Structure of a Semantic Theory, „Language” 1963/39, s. 170-210.

11 Za czołowe postaci językoznawstwa kognitywnego uważa się zwykle Ronalda Langackera, twórcę gramatyki kognitywnej i Georga Lakoffa, twórcę teorii metafory pojęciowej, a symboliczną datą dla tego ruchu jest rok 1987, kiedy zostały opublikowane ich kluczowe prace. Ogólny zarys językoznawstwa kognitywnego i charakterystykę teorii R. Langackera zob. w: M. Zeifert, Gramatyka przepisu jako przestanka decyzji interpretacyjnej, Katowice 2019, s. 37-65. Teoria G. Lakoffa w kontekście prawnym została natomiast obszernie przedstawiona w: S. Wojtczak, I. Witczak-Plisiecka, R. Augustyn, Metafory konceptualne jako narzędzia rozumowania i poznania prawniczego, Warszawa 2017.
} 
była ona rozwijana dość niezależnie na gruncie różnych dyscyplin nauki, nie tylko językoznawstwa ${ }^{12}$. Po drugie, nawet w ramach językoznawstwa stworzono różne wersje teorii prototypu $^{13}$. Poniższy opis siłą rzeczy będzie zatem nieco wybiórczy, a także - z racji ograniczeń ilościowych - niekompletny.

W literaturze przedmiotu do charakterystycznych twierdzeń teorii prototypu zalicza się następujące tezy:

1) Kategorie prototypowe nie dają się zdefiniować za pomocą zestawu cech kryterialnych (inaczej: warunków wystarczających i koniecznych).

2) Kategorie prototypowe przejawiają tzw. podobieństwo rodzinne, tzn. poszczególnych przedstawicieli kategorii łączy sieć powiązań typu: $\mathrm{AB} \mathrm{BC} \mathrm{CD}$, a zatem brak jednego zestawu cech wspólnego dla wszystkich.

3) Kategorie prototypowe przejawiają stopniowalność w zakresie przynależności do kategorii, tzn. niektórzy przedstawiciele kategorii są bardziej reprezentatywni od innych.

4) Kategorie prototypowe mają rozmyte granice ${ }^{14}$.

Ad. 1. Przykładem kategorii, której nie da się opisać za pomocą jednego zestawu cech kryterialnych, jest badana przez E. Rosch kategoria PTAK. Ptaki generalnie kojarzą nam się z lataniem, jednak bez trudu potrafimy wskazać gatunki ptaków, które tej zdolności nie posiadają (np. struś, indyk, pingwin) lub posiadają ją w bardzo ograniczonym stopniu (np. kura). Ponadto, istnieją również inne zwierzęta, które potrafią latać (np. nietoperze, owady). Ptaki zasadniczo mają skrzydła, ale ponownie - nie wszystkie (np. kiwi), poza tym skrzydła posiadają również inne zwierzęta (np. nietoperze, owady). Nie wszystkie ptaki mają typowe pióra (np. kiwi, pingwin). Natomiast wszystkie ptaki mają dzioby i składają jaja, jednak nie są to cechy wyłącznie ptasie (dzioby mają również niektóre ryby czy nawet ssaki, np. dziobak; jaja składa również większość gadów i ssaki z rodziny stekowców). A zatem zbiór cech, które skłonni bylibyśmy uznać za charakterystyczne dla kategorii PTAK nie daje się odnieść do wszystkich znanych nam okazów tej kategorii i tylko tej kategorii; tym samym - nie może on uchodzić za zbiór cech kryterialnych (wystarczających i koniecznych) ${ }^{15}$.

Ad. 2. „Podobieństwo rodzinne” to termin zaproponowany przez Ludwiga Wittgensteina, a podchwycony i ochoczo wykorzystywany przez lingwistów kognitywnych. Oznacza strukturę podobieństw, z których żadne nie jest wspólne wszystkim elementom kategorii. L. Wittgenstein posłużył się tu przykładem kategorii GRA: „Gdy im się bowiem przypatrzysz, to nie dojrzysz wprawdzie niczego, co byłoby wszystkim wspólne, dostrzeżesz natomiast podobieństwa, pokrewieństwa - i to cały szereg. (...) widzimy skomplikowaną siatkę zachodzących na siebie i krzyżujących się podobieństw, podobieństw w skali dużej i małej. Podobieństw tych nie potrafię scharakteryzować lepiej niż jako «podobieństwa rodzinne», gdyż tak właśnie splatają się i krzyżują rozmaite podobieństwa członków jednej rodziny: wzrost, rysy twarzy, kolor oczu, chód, temperament itd., itd." ${ }^{\prime 6}$.

\footnotetext{
12 Por. D. Geeraerts, Prospects..., s. 2.

13 W konsekwencji termin „teoria prototypu” należy uznać za pewien skrót myślowy, zresztą nieczęsto używany przez samych lingwistów kognitywnych, por. na ten temat: D. Geeraerts, Prospects..., s. 1, przypis 1.

14 D. Geeraerts, Prospects..., s. 5 i n.

15 Por. G. Kleiber, Semantyka prototypu. Kategorie i znaczenie leksykalne, Kraków 2003, s. 55 i n.

16 L. Wittgenstein, Dociekania filozoficzne, Warszawa 2004, s. 50-51.
} 
Ad. 3. Stopniowalność w obrębie kategorii jest cechą, która wiąże się ściśle z pojęciem prototypu. Prototyp rozumiany jest jako „najlepszy”, tzn. najbardziej reprezentatywny lub „centralny” przedstawiciel kategorii, względnie - wiązka najbardziej charakterystycznych cech danej kategorii ${ }^{17}$. Przynależność innych obiektów do danej kategorii jest mierzona ich podobieństwem do prototypu. Podobieństwo to może przybierać różne wartości, co skutkuje uznaniem jednych obiektów za „lepszych”, innych zaś za „gorszych” przedstawicieli kategorii. W przypadku kategorii PTAK zapewne skłonni bylibyśmy uznać wróbla, kruka czy orła za „lepszych” jej przedstawicieli niż pingwin, emu czy kiwi, które przejawiają mniej typowo ptasich cech. Stopniowalność w obrębie kategorii jest dość dobrze udokumentowana na gruncie empirycznym - potwierdza ją szereg efektów eksperymentalnych $^{18}$. Co ciekawe, stopniowalność przejawiają nawet kategorie sztuczne, dające się bez problemu zdefiniować za pomocą klasycznej definicji (np. LICZBA PARZYSTA) oraz kategorie percepcyjne, ściśle związane z ludzkimi zmysłami (np. nazwy barw) ${ }^{19}$.

Ad. 4. Rozmycie granic kategorii jest najbardziej kontrowersyjną cechą kategorii prototypowych. Intuicyjnie czujemy, że chociaż pingwin jest niezbyt typowym gatunkiem ptaka, jest on jednak w stu procentach ptakiem. A zatem należy wyraźnie odróżnić stopniowalność w obrębie kategorii od rozmycia jej granic. Za kategorie rozmyte można bez wątpienia uznać nazwy barw. Nie da się precyzyjnie wyznaczyć granicy między np. CZERWONYM i POMARAŃCZOWYM - kolory te płynnie przechodzą jeden $\mathrm{w}$ drugi ${ }^{20}$. Cecha ta nie dotyczy jednak wyłącznie pojęć percepcyjnych, ale także np. artefaktów kulturowych ${ }^{21}$.

Warto zauważyć, że teoria prototypu wywołuje skutki zarówno w odniesieniu do intensji, jak i ekstensji pojęć (nazywanych tu kategoriami). Cechy pierwsza (brak definicji klasycznej) i druga („podobieństwo rodzinne”) dotyczą struktury wewnętrznej kategorii, jej znaczenia. Cechy trzecia (stopniowalność) i czwarta (rozmycie granic) dotyczą natomiast relacji kategorii do świata, a więc oznaczania (referencji) ${ }^{22}$. Bardzo istotne jest podkreślenie, że omówione powyżej cztery cechy prototypowości nie muszą występować łącznie. I tak: brak klasycznej definicji nie oznacza automatycznie, że kategoria będzie miała rozmyte granice; nie zawsze stopniowalność przynależności do kategorii będzie się wiązała z występowaniem struktury „podobieństwa rodzinnego” itd. Innymi słowy, pojęcie kategorii prototypowej samo w sobie ma charakter prototypowy ${ }^{23}$. Podobny problem dotyczy samego pojęcia prototypu. Bywa ono przez poszczególnych badaczy odnoszone do różnych bytów, w tym: konkretnego okazu danej kategorii, wyidealizowanego, najbardziej reprezentatywnego okazu, okazu domyślnego, wiązki cech „diagnostycznych” dla danej kategorii ${ }^{24}$. Wielu badaczy zwraca jednak uwagę, że poszukiwanie definicji prototypu byłoby zanegowaniem teorii, która wzięła od niego swoją nazwę. W rezultacie, lingwiści posługują się zazwyczaj pojęciem prototypu bez jego

17 G. Kleiber, Semantyka..., s. 59-78.

18 Por. E. Rosch, Cognitive..., s. 224 i n.; G. Kleiber, Semantyka..., s. 57-58.

19 D. Geeraerts, Prospects..., s. 8-9.

20 Na gruncie np. języka polskiego, w którym występują nazwy dla obu tych barw. Por. J. Taylor, Kategoryzacja ..., s. 20-43 i powołaną tam literaturę.

21 Por. G. Kleiber, Semantyka..., s. 53.

22 D. Geeraerts, Prospects..., s. 7.

23 D. Geeraerts, Prospects..., s. 5 i n.

24 J. Taylor, Prototypes in Cognitive Linguistics, w: P. Robinson, N.C. Ellis (red.) Handbook of Cognitive Linguistics and Second Language Acquisitions, Nowy Jork 2008, s. 42-47. Sama E. Rosch przestrzegała przed utożsamianiem prototypu z jakąkolwiek mentalną reprezentacją kategorii i wskazywała, że: „mówienie o prototypie jest jedynie wygodną gramatyczną fikcją". E. Rosch, Principles..., s. 15. 
precyzowania, intuicyjnie. W nowszych publikacjach podkreśla się, że występowanie prototypów jest jedynie skutkiem ubocznym pewnych procesów poznawczych. Mówi się raczej o efektach prototypowych, a ich źródeł poszukuje się w oparciu na innych koncepcjach wypracowanych przez językoznawstwo kognitywne ${ }^{25}$.

Wielu językoznawców kognitywnych (w szczególności jeden z ojców-założycieli tego kierunku, G. Lakoff) wiąże z pojęciem prototypu jeszcze jedną cechę, a mianowicie „doświadczeniowy" (experiental) charakter kategorii pojęciowych ${ }^{26}$. Przyjmują oni, że ludzki system pojęciowy kształtuje się na podstawie sensomotorycznych interakcji ze światem (tzw. ucieleśniony umysł - embodied mind $)^{27}$. Podkreślają również rolę społecznego kontekstu (określanego jako ramy, skrypty lub wyidealizowane modele poznawcze) w tworzeniu pojęć i posługiwaniu się nimi ${ }^{28}$. Wiąże się to $\mathrm{z}$ uznaniem dynamicznego charakteru kategorii pojęciowych. Wątek ten ma charakter epistemologiczny i chociaż jest w teorii prototypu dość powszechny, nie ma charakteru niezbędnego dla jej lingwistycznej operatywności ${ }^{29}$. Niezbędne jest natomiast zanegowanie istnienia czysto językowego rodzaju wiedzy (tzw. wiedza semantyczna lub słownikowa), który odpowiadałby za znaczenie wyrazów $^{30}$. Badania prowadzone w ramach teorii prototypu wykazują jednoznacznie, że rozumienie pojęć odbywa się zawsze w kontekście szerszej wiedzy o świecie (tzw. wiedzy encyklopedycznej) i nie daje się z niej wypreparować w sposób postulowany przez przedstawicieli językoznawstwa strukturalnego ${ }^{31}$.

Biorąc pod uwagę rolę kategoryzacji w stosowaniu prawa, teoria prototypu jawi się jako niezwykle doniosła dla nauki prawa i praktyki prawniczej. W piśmiennictwie polskim została ona jak dotąd zaledwie dostrzeżona ${ }^{32}$. Od kilkunastu lat bywa natomiast wykorzystywana przez prawników anglosaskich. Poszczególni autorzy sięgają do niej przy omawianiu sporów doktrynalnych i filozoficznych ${ }^{33}$, teoretycznych i praktycznych aspektów interpretacji prawa ${ }^{34}$, jak również szczegółowych problemów prawa konstytucyjnego ${ }^{35}$, karnego $^{36}$, patentowego ${ }^{37}$ czy czekowego $^{38}$.

25 G. Lakoff, Kobiety, ogień i rzeczy niebezpieczne, Kraków 2011, s. 41-44; G. Kleiber, Semantyka..., s. 152 i n.

26 G. Lakoff, Kobiety..., s. 261 i n.

27 G. Lakoff, Kobiety..., s. 267 i n.

28 Por. np. Ch. Fillmore, An Alternative to Checklist Theories of Meaning, „Proceedings of the First Annual Meeting of the Berkeley Linguistics Society” 1975, s. 124 i n.; G. Lakoff, Kobiety..., s. 66-74 i n.; R. Langacker, Gramatyka kognitywna. Wprowadzenie, Kraków 2009, s. 61-84.

29 D. Geeraerts, Prospects..., s. 6.

30 D. Geeraerts, Prospects..., s. 2-3.

31 Por. np. Charlesa Fillmora słynną krytykę definicji pojęcia KAWALER w: Ch. Fillmore, An Alternative..., s. 128 i n.; R. Langacker, Gramatyka..., s. 70 i n.

32 Z. Tobor, W poszukiwaniu intencji prawodawcy, Warszawa 2013, s. 214; M. Zeifert, Gramatyka..., s. $78-83$.

33 S.L. Winter, A Clearing In the Forest: Law, Life, and Mind..., s. 141-144, 154-155 i n.; S.L. Winter, Frame Semantics and the Internal Point of View, w: M. Freeman, F. Smith (red.), Current Legal Issues: Law and Language, Oksford 2013, s. 115-127.

34 Por. L.M. Solan, The Language..., s. 41-79; L.M. Solan, Why Laws Work Pretty Well, But Not Great: Words and Rules in Legal Interpretation, „Law and Social Inquiry” 2001/26, s. 243-270; M.R. Smith, Linguistic Hooks: Overcoming Adverse Cognitive Stock Structures in Statutory Interpretation, „Legal Communication \& Rhetoric: JALWD” 2011/1, s. 1-36; J.G. Christy, A Prolegomena to Federal Statutory Interpretation: Identifying the Sources of Interpretive Problems, „Mississippi Law Review” 2006/76, s. 55-134.

35 A.E. Falcone, Law and Limits: How Categories Construct Constitutional Meaning, „University of Pennsylvania Journal of Constitutional Law" 2006/5, s. 1005-1032.

36 S.P. Green, Prototype Theory and the Classification of Offenses in a Revised Model Penal Code: A General Approach to the Special Part, „Buffallo Criminal Law Review” 2000/4, s. 301-339.

37 K. Osenga, A Penguin's Defence of the Doctrine of Equivalents: Applying Cognitive Linguistics to Patent Law, „New York University Journal of Law \& Liberty” 2011/6, s. 313-358. Por. J.V. Manzanares, Cognitive Linguistics and the Law, „Anuari de Filologia. Estudis de Linguistica” 2014/4, s. 185-200.

38 J.W. Hamilton, Theories of Categorization: A Case Study of Cheques, „Canadian Journal of Law and Society” 2002/1, s. $115-138$. 


\section{Studium przypadku - co to jest piwo?}

Znaczenie teorii prototypu dla wykładni prawa najłatwiej będzie pokazać na przykładzie rzeczywistej wątpliwości interpretacyjnej. Polski producent wprowadził na rynek produkt będący gazowanym napojem alkoholowym o smaku owocowym. W odróżnieniu od innych napojów tego typu, w omawianym produkcie alkohol był uzyskiwany nie poprzez dodanie spirytusu, lecz poprzez dodanie przefermentowanej mieszaniny syropu glukozowego (ponad 90\%), ekstraktu słodowego (poniżej 8\%) i innych substancji. Z powodu obecności słodu w półprodukcie producent zakwalifikował produkt jako „mieszaninę piwa z napojami bezalkoholowymi”, co uprawniało go do stosowania preferencyjnej stawki podatku akcyzowego (jak dla piwa). Właściwy organ podatkowy zakwestionował taką kwalifikację, podnosząc że z uwagi na znikomą zawartość słodu produkt stanowi w rzeczywistości „napój na bazie pozostałego napoju fermentowanego i napoju bezalkoholowego", co skutkowało zmianą stawki akcyzy istotnie niekorzystną dla producenta. W praktyce polskich organów podatkowych i sądów administracyjnych od lat funkcjonowała bowiem reguła, zgodnie z którą minimalna zawartość słodu w piwie nie mogła być niższa niż surowców niesłodowanych. Innymi słowy, w ocenie organu słód powinien stanowić ponad 50\% zasypu, z którego powstaje brzeczka (tj. roztwór wodny poddawany następnie fermentacji).

Polska ustawa o podatku akcyzowym w zakresie definicji napojów alkoholowych odsyła do regulacji unijnych - tzw. nomenklatury scalonej (dalej: „CN”) ${ }^{39}$. Unijna regulacja przewiduje dwie relewantne kategorie:

1) „Piwo otrzymywane ze słodu (pozycja 2203)”,

2) „Pozostałe napoje fermentowane (...) (pozycja 2206) ${ }^{40} "$.

Wątpliwość dotyczyła zatem tego, czy nieznaczna ilość słodu (poniżej 8\%) wykorzystywana do wyrobu półproduktu uprawnia do uznania go za „piwo otrzymywane ze słodu”, a w rezultacie - do zakwalifikowania końcowego produktu jako „mieszaniny piwa z napojami bezalkoholowymi”. Organ podatkowy wątpliwości nie miał. Jego zdaniem zastosowanie takiej kwalifikacji służyło wyłącznie wprowadzeniu w błąd organu podatkowego, skutkującym wyłudzeniem różnicy w wysokości podatku akcyzowego na szkodę Skarbu Państwa. Wobec producenta wszczęto postępowanie karne, które zakończyło się skazaniem w pierwszej instancji. W toku rozpoznawania apelacji sąd okręgowy wystąpił jednak do Trybunału Sprawiedliwości Unii Europejskiej z pytaniem prejudycjalnym dotyczącym prawidłowej interpretacji pozycji 2203 CN, tj. kategorii „piwo otrzymywane ze słodu”.

Trybunał Sprawiedliwości Unii Europejskiej ${ }^{41}$ w pierwszej kolejności przywołał (niewiążącą) notę wyjaśniającą do tej pozycji, która zawiera dość obszerny opis piwa i procesu jego produkcji, jednak nie przesądza dokładnego składu tego napoju alkoholowego. Kolejno Trybunał podniósł, że unijne przepisy wymagają, by w piwie znalazł się słód

39 Art. 94 ust. 1 i art. 96 ust. 4 pkt 2 ustawy z 6.12.2008 r. o podatku akcyzowym (tekst jedn.: Dz. U. z 2019 r. poz. 864 ze zm.).

40 Załącznik I do rozporządzenia Rady (EWG) nr 2658/87 w sprawie nomenklatury taryfowej i statystycznej oraz w sprawie Wspólnej taryfy celnej (Dz. Urz. EWG L 256 z 1987 r., s. 1), w wersji wynikającej z rozporządzenia Komisji (EWG) nr 2587/91 z 26.07.1991 r. (Dz. Urz. EWG L 259 z 1991 r., s. 1) w zw. z art. 2 dyrektywy Rady 92/83/EWG z 19.10.1992 r. w sprawie harmonizacji struktury podatków akcyzowych od alkoholu i napojów alkoholowych (Dz. Urz. EWG L 316 z 1992 r., s. 21).

41 Wyrok TSUE z 13.03.2019 r., C-195/18, B.S. v. Prokuratura Okregowa w Piotrkowie Trybunalskim i in., ECLI:EU:C:2019:197, dalej: „wyrok C-195/18, B.S.”. 
(„piwo otrzymywane ze słodu”), ale nie przewidują jego minimalnej ilości, jak również nie zakazują obecności innych surowców, w tym syropu glukozowego, w brzeczce. Z powyższych względów TSUE orzekł, że: „półprodukt (...), otrzymywany z brzeczki zawierającej mniej składników słodowych niż składników niesłodowych, (...), można zakwalifikować jako "piwo otrzymywane ze słodu» (...), o ile cechy organoleptyczne tego wyrobu odpowiadają cechom organoleptycznym piwa, czego zweryfikowanie należy do sądu odsyłającego".

Wyrok C-195/18, B.S. odbił się szerokim echem w polskich mediach. Dziennikarze i eksperci podatkowi nie kryli rozczarowania, zgodnie przewidując piwną katastrofę: „Kuriozalny wyrok sprawi, że browary będą oszczędzać na akcyzie, a na półkach pojawią się wyroby "piwopodobne»"42. Ocena potencjalnego wpływu wyroku na rynek piwa nie należy oczywiście do moich kompetencji. Chciałbym się jednak pochylić nad jego wymiarem teoretycznoprawnym, który wydaje mi się niezwykle interesujący. Trybunał Sprawiedliwości stanął bowiem przed pytaniem natury par excellence semantycznej: co to jest piwo? Udzieloną w wyroku odpowiedź można by sparafrazować następująco: piwem jest to, co ma cechy piwa - a w jeszcze prostszej wersji - piwem jest to, co przypomina piwo. $\mathrm{Z}$ analitycznego punktu widzenia definicja taka jest oczywiście tautologiczna i nie oferuje żadnego użytecznego kryterium. Sądzę wszakże, że teoria prototypu pozwala ukazać ją w całkiem innym świetle.

W tym miejscu wypada pokrótce przybliżyć czytelnikowi proces produkcji piwa ${ }^{43}$. Piwo zazwyczaj wytwarzane jest z czterech surowców: wody, słodu, drożdży i chmie$\mathrm{lu}^{44}$. Słód dodaje się do wody w określonej temperaturze i przygotowuje roztwór, czyli brzeczkę (tzw. zacieranie). Następnie brzeczkę gotuje się, dodając przyprawę w postaci chmielu (tzw. warzenie). Po schłodzeniu brzeczkę zadaje się drożdżami, które w trwającym zwykle kilka tygodni procesie fermentacji alkoholowej przetwarzają cukry i tlen w alkohol etylowy i dwutlenek węgla (który zapewnia piwu nagazowanie). Trybunał słusznie jednak zauważył, że do produkcji piwa wykorzystywane są również inne surowce, w szczególności niesłodowane zboża i różnego rodzaju cukry. Nie jest to bynajmniej wymysł współczesnych producentów. Przykładowo, tradycyjny belgijski witbier powinien zawierać w zasypie ponad 50\% niesłodowanej pszenicy; angielski stout swoją czarną barwę zawdzięcza dodatkowi palonego niesłodowanego jęczmienia; wiele belgijskich piw klasztornych powstaje z dodatkiem cukru czy mąki pszennej. Przykłady można by mnożyć. Słusznie więc TSUE uznał, że określona ilość słodu nie może stanowić cechy definicyjnej piwa.

To samo powiedzieć można o pozostałych surowcach. Woda jest niezbędna do wyprodukowania piwa, ale znajduje się w także w składzie niemal każdego innego napoju (alkoholowego i bezalkoholowego), a zatem nie może stanowić surowca definiującego piwo. Chmiel jest w piwie - wbrew popularnemu przeświadczeniu - dodatkiem opcjonalnym. Istnieją tradycyjne style piwa, w których zamiast chmielu używa się mieszanki

42 M. Milan, Piwny wyrok, „Gazeta Finansowa”, 14.04.2019 r., https://gf24.pl/biznes-i-gospodarka/item/1894-piwny-wyrok, dostęp: 16.04.2020 r. Por. jednak zgoła odmienny komentarz popularnego eksperta piwnego, Tomasza Kopyry: Czy wyrok TSUE zniszczy polskie piwo, YouTube.com, 14.03.2009 r. https://youtu.be/cb0lmx7_Mac, dostęp: 18.10.2019 r.

43 Informacje na temat procesu produkcji i stylów piwnych pochodzą głównie z: T. Kopyra, Piwo. Wszystko, co musisz wiedzieć, żeby nie wyjść na glupka, Kraków 2016. Zob. też internetowa Polska Encyklopedia Piwowarstwa Domowego (www.wiki.piwo.org); blog Doroty Chrapek (http://blog.homebrewing.pl), blog Bartosza Markowskiego (www.beerfreak.pl), serwis Brew Your Own (https://byo.com).

44 Taki skład piwa przewidywało m.in. Bawarskie Prawo Czystości (Reinheitsgebot) z 1516 r., które istotnie wpłynęło na rynek piwa w nowożytnych Niemczech. 
ziół (tzw. gruit) czy jałowca (fińskie sahti). Również w niektórych piwach kwaśnych (szczególnie z dodatkiem owoców) rezygnuje się z chmielu. Jeśli chodzi o drożdże, to do produkcji piwa używa się zwykle tzw. drożdży piwowarskich, innych niż drożdże winiarskie, gorzelnicze czy piekarnicze. Nasuwają się tu dwa zastrzeżenia. Po pierwsze, można zrobić piwo również z drożdży nie-piwowarskich (np. fińskie sahti tradycyjnie fermentowane jest drożdżami piekarniczymi, belgijski lambic przechodzi tzw. fermentację spontaniczną z udziałem „dzikich” szczepów drożdży). Po drugie, użycie drożdży piwowarskich nie może definiować piwa, bowiem pojęcie drożdży piwowarskich zakłada pojęcia piwa (błąd circulus in definiendo). Wreszcie, poza wymienionymi czterema typowymi składnikami, piwo może zawierać przeróżnego rodzaju dodatki, dodawane na różnych etapach produkcji takie jak: miąższ owocowy, soki owocowe, skórki cytrusów, przyprawy, zioła, kawa, czekolada, laktoza, bakterie kwasu mlekowego itd.

Jak zatem widzimy, nie sposób sformułować definicji piwa odwołującej się do surowców użytych do jego produkcji. Innymi słowy, nie sposób sformułować klasycznej definicji, polegającej na wskazaniu warunków (tu: składników) koniecznych i wystarczających. Trybunał poszedł inną drogą, odwołał się bowiem do cech organoleptycznych produktu. O jakie cechy może chodzić? Pomocne mogą tu być kryteria oceny piwa podczas konkursów piwnych, wśród których znajdziemy zwykle: wygląd, aromat, smak, goryczkę, odczucie w ustach, ogólne wrażenia. Wygląd obejmuje barwę, klarowność i jakość piany. Piwo najczęściej kojarzone jest z jasną, złocistą barwą. Może jednak przybierać różne barwy, co wynika z rodzajów użytych słodów i ewentualnie innych surowców: od słomkowej (np. witbier), przez bursztynową (np. amber ale), czerwoną (np. irish red ale), brązową (np. bock, porter angielski) do całkiem czarnej (np. stout, porter bałtycki). Również klarowność piwa podlega znacznym wahaniom, w zależności od użytych surowców, procesu filtracji itd. Podobnie z pianą: w niektórych stylach piw (np. piwa z dodatkiem owoców czy piwa o bardzo dużej zawartości alkoholu) piana jest śladowa lub w ogóle nie powstaje. Aromat piwa może być bardzo różnorodny, a wynika z użytych słodów, gatunków chmieli i ewentualnie dodatków, np. przypraw. Bawarski hefeweizen słynie $\mathrm{z}$ aromatu bananowo-goździkowego, angielski stout pachnie kawą i czekoladą, niemiecki bock ma nuty karmelowo-chlebowe, amerykańskie india pale ale zaskakuje aromatami cytrusów, owoców tropikalnych, żywicy, kwiatów lub skoszonej trawy. Smak piwa może być równie różnorodny jak aromat, z którym zresztą jest ściśle skorelowany. Popularny jasny lager ma lekko słodowy, mdły smak i w niczym nie przypomina czekoladowo-likierowego porteru bałtyckiego czy kwaśno-słonego, jogurtowego gose. Goryczka piwna jest zazwyczaj zasługą chmielu, ale jej stopień różni się diametralnie w zależności od stylu piwa. Niektóre style są w ogóle pozbawione goryczki, a chmiel służy wyłącznie dla zapewnienia smaku lub aromatu. Podobnie jest z wysyceniem piwa dwutlenkiem węgla - zasadniczo im mocniejsze piwo, tym powinno być mniej nagazowane. Przykładowo, angielskie barley wine pod względem nagazowania (jak i zawartości alkoholu) przypomina - zgodnie z nazwą - raczej wino niż piwo. Podsumowując ten wątek rozważań: nie sposób mówić o wyglądzie, aromacie czy smaku definiującym piwo.

Wydaje się więc, że cechy organoleptyczne piwa nie dają się ułożyć w zestaw cech wystarczających i koniecznych. Znamienne, że nie podał ich również TSUE pomimo odwołania się do nich w rozstrzygnięciu. Czy zatem rozstrzygnięcie Trybunału da się teoretycznie uzasadnić? Sądzę, że jest to możliwe na gruncie kognitywnej teorii prototypu. Opisane powyżej problemy definicyjne prowadzą do wniosku, że PIWO jest kategorią prototypową - wykazuje co najmniej trzy spośród omówionych wcześniej cech 
prototypowości. Po pierwsze, nie da się go zdefiniować w oparciu o zestaw warunków wystarczających i koniecznych ${ }^{45}$. Po drugie, przejawia strukturę „podobieństwa rodzinnego", tj. charakterystyczne cechy krzyżują się pomiędzy poszczególnymi okazami tej kategorii $^{46}$. Po trzecie, można mówić o bardziej i mniej typowych rodzajach (stylach) piwa $^{47}$. Pozostaje pytanie o czwarty z efektów prototypowych, tj. rozmytość granic kategorii. Nie jestem przekonany, czy PIWO należy uznać za kategorię o rozmytych granicach. Style piwa, które w naszym kraju uchodzą za nietypowe (np. belgijski lambic czy angielski russian imperial stout) bez wątpienia są również piwem, podobnie jak pingwin jest bez wątpienia ptakiem.

Chciałbym zwrócić uwagę jeszcze na jedną kwestię. Kategoria PIWO różni się od kategorii zwykle przywoływanych w ramach omawiania teorii prototypu, jak PTAK, MEBEL, OWOC czy - popularny także wśród filozofów prawa - POJAZD ${ }^{48}$. Te ostatnie kategorie stanowią tzw. kategorie poziomu nadrzędnego (superordinate level) o stosunkowo niewielkiej liczbie wspólnych cech, braku wspólnego kształtu czy wspólnych schematów motorycznych wykorzystywanych do interakcji ze wszystkimi przedstawicielami kategorii ${ }^{49}$. Taka charakterystyka łatwo tłumaczy występowanie przypadków granicznych. PIWO stanowi natomiast kategorię poziomu podstawowego (basic level) ${ }^{50}$. Różnicę tę można przedstawić następująco: kiedy wskażę palcem na samochód marki DACIA LODGY i zapytam: „co to jest?” - w braku szczególnego kontekstu odpowiedzią będzie: „samochód” (a nie: „pojazd”, „samochód osobowy”, „miniwan” itd.). Z kolei, jeśli wskażę palcem na szklankę piwa typu pils, wówczas najbardziej neutralną odpowiedzią będzie: „piwo” (a nie: „napój”, „napój alkoholowy”, „piwo dolnej fermentacji”, ,jasny lager”, „pils” itd.). Kategorie poziomu podstawowego znajdują się na niższym poziomie abstrakcji, mają znacznie więcej wspólnych cech, wspólny kształt, wspólny schemat motoryczny wykorzystywany do interakcji ze wszystkimi przedstawicielami kategorii ${ }^{51}$. W ich przypadku efekty prototypowe są mniej oczywiste, bowiem nie można ich przypisać typowej nieostrości pojęć (vagueness), wynikającej z dużego stopnia ogólności.

\section{Wnioski}

Przyjmijmy zatem, że PIWO jest pojęciem prototypowym. Co z tego ustalenia wynika dla oceny wykładni przeprowadzonej przez TSUE? Z pewnością uzasadnia to odstąpienie od formułowania klasycznej definicji piwa, jako zestawu cech wystarczających i koniecznych. Trybunał rozstrzygnął, że produkt może być uznany za piwo, jeśli odpowiada cechom organoleptycznym piwa. Nie podjął się jednak ustalenia wymaganego katalogu tych cech ani nie przesądził stopnia odpowiedniości. W świetle powyższych rozważań

$45 \mathrm{Z}$ uwagi na ograniczone ramy opracowania nie rozważam tu wszystkich możliwości. Można próbować definiować piwo np. z punktu widzenia procesu produkcji, sposobu podania czy dystrybucji. Sądzę, że próby te są ostatecznie również skazane na niepowodzenie.

46 Przykładowo: bawarski hefeweizen jest podobnie jasny jak czeski pilsner, który z kolei stopniem goryczki odpowiada zwykle angielskiemu pale ale, które $\mathrm{z}$ amerykańskim india pale łączą żywiczne nuty smakowe itd.

47 W naszym kraju prototypowym piwem będzie zapewne jasny lager o złocistej barwie, niewielkiej goryczce, lekko słodowym aromacie i smaku, sporym wysyceniu i obfitej białej pianie.

48 Por. H.L.A. Hart, Positivism and the Separation of Law and Morals, w: R. Dworkin (red.), The Philosophy of Law, Oksford 1977(1958), s. 22 i n.

49 Por. E. Rosch, Natural..., s. 4-10; J. Taylor, Kategoryzacja ..., s. 76-82; E. Rosch, Cognitive ..., s. 224.

50 Kategorię poziomu nadrzędnego w tym przypadku stanowi kategoria NAPÓJ ALKOHOLOWY.

51 Por. E. Rosch, Natural..., s. 4-10; J. Taylor, Kategoryzacja .., s. 76-82; G. Kleiber, Semantyka ..., s. 82-98. 
jest to całkowicie zrozumiałe. Nie da się sformułować zestawu cech organoleptycznych, które charakteryzowałyby każde piwo. Przejawiają one raczej strukturę „podobieństwa rodzinnego". Również stopień odpowiedniości (czyli ilość spełnianych cech) nie może być sztywno ustalony. Istnieją bardziej i mniej typowe rodzaje piwa. Jak wspomniałem, rozstrzygnięcie TSUE można by sparafrazować następująco: piwem jest to, co przypomina piwo. Teoria prototypu pozwala zinterpretować tę definicję w sposób, który eliminuje tautologię: piwem jest to, co ( $\mathrm{w}$ wystarczającym stopniu) przypomina prototypowe piwo.

Takie postawienie sprawy nie usuwa, rzecz jasna, wątpliwości interpretacyjnej. W szczególności aktualne pozostają następujące pytania: czym cechuje się prototypowe piwo? Jaki stopień podobieństwa do prototypu jest wymagany, by przesądzić o klasyfikacji danego produktu jako piwa? Przypomnijmy, że co do zasady nie powinniśmy od teorii lingwistycznych oczekiwać rozwiązania prawniczych dylematów interpretacyjnych: „Kiedy powstaje problem interpretacyjny, językowe i poznawcze podstawy wycofują się, robiąc miejsce rozważaniom prawnym i politycznym, które sugerują, jak go rozwiązać"s2. W żadnym przypadku nie oznacza to jednak ich bezużyteczności. Wiedza lingwistyczna „może pozwolić prawnikom dostrzec kontury problemów językowych i pomóc sędziom wysłowić językowe aspekty tych problemów w wydawanych przez nich orzeczeniach. Co więcej, może pomóc zrozumieć, w jaki sposób problemy te powstają"53. Słowa te są szczególnie aktualne w odniesieniu do teorii prototypu, której ambicją jest rekonstrukcja rzeczywistych procesów psychologicznych odpowiadających za proces kategoryzacji. Wartość teorii prototypu dla prawników nie polega zatem na wyrugowaniu wątpliwości interpretacyjnych, ale na ich odmiennej konceptualizacji.

Trzeba w tym miejscu zauważyć, że nauka prawa i praktyka prawnicza są mocno związane z klasyczną teorią kategoryzacji, zapośredniczoną przez aparaturę semiotyki logicznej i logiki formalnej ${ }^{54}$. Jak ujął to jeden $\mathrm{z}$ autorów: „Ustawy są generalnie pisane jak klasyczne definicje, które z kolei jawią się nam jako reguły wysławiające warunki wystarczające i konieczne dla prawidłowego używania słów"55. Obserwujemy to na wielu płaszczyznach: dogmatycy spierają się o istotę znaczenia poszczególnych terminów ustawowych czy instytucji prawnych ${ }^{56}$, studenci prawa uczą się precyzyjnego budowania definicji, akty prawne zawierają lepiej lub gorzej sformułowane definicje legalne, sądy powszechnie korzystają z definicji doktrynalnych czy słownikowych.

Również analizy semantyczne języka prawnego prowadzone są zwykle na podstawie klasycznej teorii kategoryzacji. Rodzi to oczywiste konsekwencje dla teorii wykładni. Wątpliwości kwalifikacyjne, takie jak omówiony powyżej przypadek, są zwykle konceptualizowane jako problem nieostrości zakresu nazwy wynikający z nieokreśloności jej treści ${ }^{57}$. Rozwiązaniem tego problemu jest ustalenie relewantnej cechy konstytutywnej

52 L.M. Solan, Why Laws..., s. 22. Na rodzimym gruncie bardzo podobną myśl wyrazil już dawno Tomasz Gizbert-Studnicki. Por. T. Gizbert-Studnicki, Teoria prawa, filozofia języka, lingwistyka, „Studia Filozoficzne” 1985/2-3, s. 81.

53 S. Schane, Language and the Law, Londyn-Nowy Jork 2006, s. 49.

54 Por. np. Z. Ziembiński, Logika praktyczna, Warszawa 1996, w szczególności s. 29-31.

55 L.M. Solan, The Language..., s. 18.

56 Por. np. wyrok Wojewódzkiego Sądu Administracyjnego (dalej: „WSA”) w Łodzi z 25.06.2009 r. (I SA/Ld 172/09), LEX nr 532860: „Istotą pojęcia «likwidacja środka trwałego» jest trwała, nieodwracalna utrata kontroli podatnika nad środkiem trwałym”; wyrok WSA w Warszawie z 12.09.2017 r. (III SA/Wa 2835/16), LEX nr 2393288: „Z istoty pojęcia «osoby samotnie wychowującej dziecko» wynika bowiem, że jest to osoba, która...”. W literaturze: „Aby umowa miała charakter umowy o kredyt konsumencki, konieczne, a zarazem wystarczające jest łączne spełnienie następujących przesłanek: (...)”. D. Rogoń, Komentarz do art. 2 ustawy o kredycie konsumenckim, LEX/el. 2002.

57 Por. np. Z. Ziembiński, Logika ..., w szczególności s. 34-36; M. Zieliński, Wykładnia prawa. Zasady, reguty, wskazówki, Warszawa 2017, s. 155-156; T. Gizbert-Studnicki, Typy nieostrości, w: T. Gizbert-Studnicki, Pisma wybrane, Warszawa 2019, s. 64 i n. 
danej nazwy i wytyczenie granicy pojęcia ustawowego ${ }^{58}$. Warto zwrócić uwagę, że taką właśnie strategię interpretacyjną przyjęły organy podatkowe w przedmiotowej sprawie, domagając się przesądzenia, że w odniesieniu do piwa cechą relewantną jest zawartość słodu w zasypie, a granicą pojęcia jest $50 \%$.

Opisane podejście nasuwa różne zastrzeżenia. Po pierwsze, wytyczenie granic pojęć języka naturalnego - takich jak piwo - w wielu przypadkach będzie miało charakter arbitralny $^{59}$. Po drugie, obiektywizm i przewidywalność, jakie ten zabieg obiecuje są iluzoryczne z uwagi na zjawisko otwartej struktury pojęć (open texture) ${ }^{60}$. Teoria prototypu, inspirowana m.in. ideami późnego Ludwiga Wittgensteina i Friedricha Waismanna ${ }^{61}$ daje podstawy do odwrócenia optyki. Nie wymaga ustalania zestawu cech konstytutywnych dla danego pojęcia, uwzględnia rolę cech przypadkowych i szerokiego kontekstu pozajęzykowego w jego rozumieniu, koncentruje uwagę interpretatora na centralnym okazie kategorii i ustalaniu podobieństwa zamiast na wytyczaniu (nieistniejących obiektywnie) sztywnych granic kategorii pojęciowych. W literaturze wskazuje się, że pozwala to m.in. lepiej uchwycić naturę pojęć prawnych ${ }^{62}$, wydobyć „Zwykłe” znaczenie słów ${ }^{63}$, uzasadnić na gruncie semantycznym wykładnię „rozszerzającą” i ,zawężającą”.

Godzi się na koniec zauważyć, że problemy związane z klasyczną teorią kategoryzacji były w nauce prawa dostrzegane od wielu lat. W teorii wykładni wypracowano (lub recypowano) wiele koncepcji, które adresują te problemy. Ujmując sprawę maksymalnie szeroko, można do nich zaliczyć m.in. koncepcję otwartej struktury pojęć prawnych ${ }^{65}$, rozmaite pozajęzykowe dyrektywy interpretacyjne, rozumowanie per analogiam, koncepcję pojęć rodzinowych ${ }^{66}$, argumentację z przypadków wzorcowych ${ }^{67}$, koncepcję wielokrotnych ugruntowañ ${ }^{68}$ czy niemiecką teorię typów ${ }^{69}$. Jak wskazuje jeden $\mathrm{z}$ autorów,

58 Por. T. Gizbert-Studnicki, Typy..., s. 66. Nieco inaczej Maciej Zieliński, który postuluje „określenie nieprzekraczalnych granic pasa nieostrości”. M. Zieliński, Wyktadnia..., s. 203. Jest to jednak jedynie różnica stopnia, a założenia teoretyczne obu wskazanych autorów są tożsame.

59 Wypada przywołać znane słowa L. Wittgensteina: „W jakiż sposób zamknięte jest pojęcie gry? Co jest jeszcze grą, a co już nią nie jest? Czy możesz podać granice? Nie. Możesz je wytyczyć: dotąd bowiem jeszcze ich nie wytyczono. (Choć nigdy ci to jeszcze nie przeszkadzało posługiwać się wyrazem «gra»)”. L. Wittgenstein, Dociekania filozoficzne, Warszawa 2004, s. 52.

${ }^{60}$ „Wprowadzamy pojęcie i ograniczamy je w pewnych kierunkach (...) To wystarcza dla naszych aktualnych potrzeb i nie sięgamy dalej. Mamy tendencję do przeoczania, że istnieją inne kierunki, w których nasze pojęcie nie zostało ograniczone”. F. Waismann, Verifiability, w: A. Flew (red.), Logic and Language, Oksford 1951, s. 3. Jak zauważa T. Gizbert-Studnicki: „Z uwagi na otwartą strukturę predykatów [tj. open texture w rozumieniu Waismanna - przypis M.Z.] w prawie ogólne decyzje nie są w stanie wyeliminować nieostrości. T. Gizbert-Studnicki, Typy..., s. 71.

61 Por. Ch. Fillmore, An Alternative..., s. 123.

62 M. Bajcic, New Insights into the Semantics of Legal Concpets and the Legal Dictionary, Amsterdam-Filadelfia 2017, s. 23; S.L. Winter, A Clearing..., w szczególności s. 186-222.

63 Por. L.M. Solan, The Language..., s. 54-81; B.H. Slocum, Linguistics and 'Ordinary Meaning' Determinations, „Statute Law Review" 2012/1, s. 39-83.

64 Por. M.R. Smith, Linguistic..., s. 5 i n.

65 H.L.A. Hart, Pojęcie..., s. 171-186. Koncepcja ta przyjęła się również w polskim prawoznawstwie, por. np. J. Woleński, Logiczne problemy wyktadni prawa, Kraków 1972, s. 76-77; J. Wróblewski, Sądowe stosowanie prawa, Warszawa 1988, s. 122-123. Pomijam w tym miejscu rozbieżności między ujmowaniem otwartej struktury pojęć przez F. Waismanna i H.L.A. Harta. Por. na ten temat B. Bix, H.L.A. Hart and the "Open Texture” of Language, „Law and Philosophy” 1991/10, s. 51-72; F. Schauer, On the Open Texture of Law, „Grazer Philosophische Studien” 2013/1, s. 197-215; S. Czepita, Derywacyjna koncepcja wyktadni a zagadnienie otwartej tekstowości pojęć prawnych, w: A. Choduń, S. Czepita (red.), W poszukiwaniu dobra wspólnego. Księga jubileuszowa Profesora Macieja Zielińskiego, Szczecin 2010, s. 229-244.

66 Por. M. Zirk-Sadowki, Wprowadzenie do filozofii prawa, Warszawa 2011, s. 79 i powołaną tam literaturę.

67 Por. J. Stelmach, Wspótczesna filozofia interpretacji prawniczej, Kraków 1995 i powołaną tam literaturę.

68 Por. M. Matczak, Summa iniuria. O btędzie formalizmu w stosowaniu prawa, Warszawa 2007, passim.

69 Por. Ch. Walshaw, Interpretation is Understanding and Application: The Case for Concurrent Legal Interpretation, „Statute Law Review” 2010/2, s. 108 i powołaną tam literaturę. 
metody tzw. miękkiej analizy (soft-shoe analysis) „są, jak się wydaje, składnikiem każdej dającej się pomyśleć i sformułować filozofii interpretacji prawniczej"70.

Czy w tym kontekście teoria prototypów oferuje wykładni prawa jakąś nową jakość? Prima facie wydaje się, że może ona odegrać rolę zwornika, udzielając teoretycznego wyjaśnienia dla różnorodnych zjawisk semantycznych dostrzeganych w nauce prawa. Przypomnijmy bowiem, że dotyczy nie tylko zjawiska nieostrości, ale oferuje alternatywne ujęcie samego mechanizmu kategoryzacji ${ }^{71}$. Udzielenie kategorycznej odpowiedzi wymaga jednak dalszych badań. W pierwszej kolejności niezbędne jest przeprowadzenie pełniejszej rekonstrukcji teorii prototypu, uwzględniającej jej kontekst filozoficzny i liczne głosy krytyczne. Następnie należy ustalić relację teorii prototypu do potencjalnie konkurencyjnych koncepcji funkcjonujących w teorii wykładni. Wreszcie, omawiana teoria powinna zostać zastosowana na szerszą skalę dla problemów interpretacyjnych praktyki prawniczej.

\title{
A Judgment of the Court of Justice of the European Union from the Perspective of Cognitive Theory of Prototypes: A Case Study
}

\begin{abstract}
Interpretative doubts in the application of law are usually born of discrepancies between the statutory language and the non-linguistic reality. Therefore, they pose the problem of categorization. The theory of law and legal practice have for centuries been dominated by the classical theory of categorization, according to which conceptual categories can be described by a set of sufficient and necessary features. In the 1970s, an American researcher Eleanor Rosch conducted a series of psychological experiments that led her to question the classical theory and lay the foundations for an alternative one, known as the prototype theory. According to this approach, conceptual categories are organized around the most typical exemplars (prototypes), and membership of a category is measured by similarity to the prototype. Some of the consequences of such view are that category membership is a gradable feature and that the borderlines of categories are fuzzy. The article presents an outline of the prototype theory in the version used in cognitive linguistics. Its usefulness for the theory and practice of statutory interpretation is tested on the basis of the judgment of the Court of Justice of the European Union regarding the concept of beer. In this judgment, the CJEU refused to define the concept of beer by setting requirements as to its raw material composition and ruled that beer is a product that has organoleptic characteristics of beer. This definition on the basis of classical theory appears to be tautological, however, it finds theoretical justification in the prototype theory. In conclusions, the author indicates research problems that must be taken up in order for the prototype theory to be reliably used in jurisprudence.
\end{abstract}

Keywords: categorization, semantics, prototype theory, statutory interpretation

70 J. Stelmach, Wspótczesna filozofia..., s. 109.

71 Niektórzy autorzy wysuwają tezę, że semantyka warunków koniecznych i wystarczających (tj. klasyczna teoria kategoryzacji) stanowi szczególny przypadek semantyki opartej na prototypie, por. G. Lakoff, Kobiety..., w szczególności s. $350-370$. 


\section{BIBLIOGRAFIA / REFERENCES:}

Fillmore, C.J. (1975). An Alternative to Checklist Theories of Meaning. Proceedings of the First Annual Meeting of the Berkeley Linguistics Society 1975, 123-131.

Geeraerts, D. (1989). Prospects and problems of prototype theory. Language 27/4, 587-612.

Gizbert-Studnicki, T. (1985). Teoria prawa, filozofia języka, lingwistyka. Studia Filozoficzne 2-3, 6781.

Gizbert-Studnicki, T. (2019). Pisma wybrane. Prawo. Język, normy, rozumowania. Warszawa: Wolters Kluwer Polska.

Hart, H.L.A. (1998). Pojęcie prawa. Warszawa: Wydawnictwo Naukowe PWN.

Hart, H.L.A. (1977). Positivism and the Separation of Law and Morals. In R. Dworkin (Ed.), The Philosophy of Law. Oxford: Oxford University Press.

Katz, J.J., Fodor, J.A. (1963). The structure of a semantic theory. Language 39/2, 170-210.

Kaufmann, A. (2018). Od prawa natury i pozytywizmu prawniczego do hermeneutyki prawniczej. In J. Zajadło (Ed.), Kaufmann. Sopot: Wydawnictwo Arche.

Kleiber, G. (2003). Semantyka prototypu. Kategorie i znaczenie leksykalne. Kraków: Towarzystwo Autorów i Wydawców Prac Naukowych Universitas.

Kopyra, T. (2016). Piwo. Wszystko, co musisz wiedzieć, żeby nie wyjść na głupka. Kraków: Flow Books.

Lakoff, G. (2011). Kobiety, ogień i rzeczy niebezpieczne. Kraków: Towarzystwo Autorów i Wydawców Prac Naukowych Universitas.

Langacker, R.W. (2009). Gramatyka kognitywna. Wprowadzenie. Kraków: Towarzystwo Autorów i Wydawców Prac Naukowych Universitas.

Milan, M. (2019). Piwny wyrok. Gazeta Finansowa, https://gf24.pl/biznes-i-gospodarka/ [last access: 20.12.2019].

Rosch, E.H. (1975). Cognitive Representations of Semantic Categories. Journal of Experimental Psychology: General 104/3, 192-233.

Rosch, E.H. (1973). Natural Categories. Cognitive Psychology 4/3, 328-350.

Rosch, E.H. (1978). Principles of Categorization. In E.H. Rosch, B.B. Lloyd (Eds.), Cognition and Categorization. Hillsdale: L. Erlbaum Associates.

Slocum, B.H. (2012). Linguistics and 'Ordinary Meaning' Determinations. Statute Law Review 33/1, 173.

Solan, L. (2010). The Language of Statutes. Laws and Their Interpretation. Chicago: The University of Chicago Press.

Solan, L. (2001). Why Laws Work Pretty Well, But Not Great: Words and Rules in Legal Intrepretation. Law and Social Inquiry 26, 243-270.

Taylor, J.R. (2001). Kategoryzacja w języku. Prototypy w teorii językoznawczej. Kraków: Towarzystwo Autorów i Wydawców Prac Naukowych Universitas. 
Taylor, J.R. (2008). Prototypes in Cognitive Linguistics. In P.J. Robinson, N.C Ellis (Eds.), Handbook of Cognitive Linguistics and Second Language Acquisitions. New York: Routledge.

Tobor, Z. (2013). W poszukiwaniu intencji prawodawcy. Warszawa: Wolters Kluwer Polska.

Waismann, F. (1951). Verifiability. In A. Flew (Ed.), Logic and Language, the First Series. Oxford: Basil Blackwell.

Winter S. (2001). A Clearing In the Forest. Law, Life and Mind. Chicago: The University of Chicago Press.

Wittgenstein, L. (2004). Dociekania filozoficzne. Warszawa: Państwowe Wydawnictwo Naukowe.

Wojtczak, S., Witczak-Plisiecka, I., Augustyn, R. (2017). Metafory konceptualne jako narzędzia rozumowania i poznania prawniczego. Warszawa: Wolters Kluwer Polska.

Wróblewski, J. (1990). Rozumienie prawa i jego wykładnia. Wrocław: Zakład Narodowy im. Ossolińskich.

Zeifert, M. (2019). Gramatyka przepisu jako przestanka decyzji interpretacyjnej. Katowice: Wydawnictwo Uniwersytetu Śląskiego.

Zieliński, M. (2017). Wykładnia prawa. Zasady, reguły, wskazówki. Warszawa: Wolters Kluwer Polska. 